\title{
Islamic Philosophy on Behaviour-based Environmental Attitude
}

\author{
Mohd Nor Mamat, Siti Fatahiyah Mahamood \\ Centre for Islamic Thought and Understanding, \\ Universiti Teknologi MARA, Malaysia \\ mohdnoor@salam.uitm.edu.my
}

\begin{abstract}
This paper concludes philosophical elements regarding conceptual theory, significances of human attitude towards the environment. In a sustainable life, environmental management becomes the most crucial area to be concerned. There are many campaigns, courses and even legal enforcement to ensure the success of educating wise attitude towards environment. This could be more effective and will create eternal effects if the understanding of environmental attitude would be based on religious teachings and philosophy. Not only for Muslims, these theoretical principles were described by the Holy Book, supported with the Prophet's tradition which could also be practiced by all mankind. The Great Sustainer is the best provider of the guidelines in interacting with all entities in our environment. In addition, they are closely related to the concept of rewards, directly or delayed. This paper highlighted a conceptual framework to be understood, in order to guide the do's and don'ts, good or bad habits and positive or negative behavior towards environmental entities, including metaphysical entities. The most important point is, this philosophy would be a platform towards designing approaches, strategies or activities towards inculcating good behavior towards environment.
\end{abstract}

Keywords: Islam, environmental attitude

eISSN 2514-751X @ 2017 The Authors. Published for AMER ABRA by e-International Publishing House, Ltd., UK.. This is an open access article under the CC BY-NC-ND license (http://creativecommons.org/licenses/by-ncnd/4.0/). Peer-review under responsibility of AMER (Association of Malaysian Environment-Behaviour Researchers), ABRA (Association of Behavioural Researchers on Asians) and cE-Bs (Centre for EnvironmentBehaviour Studies), Faculty of Architecture, Planning \& Surveying, Universiti Teknologi MARA, Malaysia.

https://doi.org/10.21834/aje-bs.v2i2.179 


\subsection{Introduction}

Human being is one of the entities created by Allah in the whole ecological system. Hence, its existence is always correlated to other environmental entities. In its manifestation, Islam divides human interaction into three categories; interaction with Allah (the Creator), interaction with human beings (environmental entity of the same species) and interaction with the environment (entities other than human beings). This indicates that the perfection (syumul) of Islam hinges on application of the whole interaction between humans and the environment; physics and metaphysics. This paper highlighted an Islamic conceptual framework to be understood, in order to guide the do's and don'ts, good or bad habits and positive or negative behavior towards environmental entities, including metaphysical entities. The most important point is, this philosophy would be a platform towards designing approaches, strategies or activities towards inculcating good behavior towards environment.

\subsection{Research Objectives}

This paper is designed for the purpose of:

1. identifying the best alternative philosophy on environmentalism and environmental behavior

2. analyzing Islamic resources on attitude towards environment

3. initiating the conceptual framework of strategies in environmental behavior studies.

\subsection{Literature Review}

\subsection{Behavior Towards Environment: Islamic Views}

Most religions in the world emphasizes on human interactions with the environment in various perspectives. Jewishs, for instance, celebrate a special new year for plants and crops known as Tu Bishewat. Similarly, Christians are always exposed to fish, birds and wildlife (as per The Genesis) while Christmas and Easter songs are always related to animals and plants. Sikhs, on the other hand, believe that their God lives on the tree, dreams of animals and wakes amongst humans. Meanwhile, Buddhists celebrate several celebrations by praying for a harmonious environment (A. R. Agwan, 1997). This in a way reflects the close interaction between humans and the environment as the content of most religions in the world.

In Islam itself, human interaction with the environment is mentioned multiple times in the Holy Quran, supported by Hadith and further explained in detail by companions and scholars. The verse in the Holy Quran regarding the assignment of humans as the Caliph 
started with the general interaction between humans and the earth, and supported by many other verses.

From the (earth) did We create you, and into it shall We return you, and from it shall We bring you out once again.

(Taha: 55)

And seek the abode of the Hereafter with the wealth that Allah has given you, and do not forget your part in this world, and do favours (to others) the way Allah has favoured you, and do not seek to cause turmoil in the earth; indeed Allah does not like the mischievous.

(Al Qasas: 77)

The same applies to the Hadith by Rasulullah (PBUH), that is translated as:

This world is beautiful and green and Allah has made you His representatives on it and He sees (all things).

(Narrated by Muslim)

According to the details by previous Muslim scholars, human interaction with the environment can be concluded into a more specific interaction; such as interaction between humans and the God (as worshippers), interaction amongst humans (as human beings in a society) as well as interaction between humans and other entities (as caliphs). This interaction concept is ongoing in every mukallaf and it is carried as amanah. It is not merely an ethic or an alternative task, but an obliged duty of human beings. This is clearly explicated in the Hadith as reported by Ibnu Umar, that Rasulullah (PBUH) said:

Each of you are (appointed) leaders and each of you will be queried on matters under your responsibilities.

(Narrated by Bukhari dan Muslim)

Islam's way of life is perfect when there are two main interactions; namely hablun minallah (human interaction with Allah) and hablun minannas (human interaction with human being and environment). The detailed principles of interaction occurs naturally as guided in the wahyu.

Islam always stresses on hygiene and cleanliness of water as symbolized in the importance of purification and cleansing (istinjak). Similarly, the environment is to be kept clean by prohibition of littering and human health is to be maintained by sanitary practices as a part of the important entities in environmental ecosystem. We are also advised to consume good food (tayyibat) and prohibited from consuming dead animals, blood, etc. These examples demonstrate that Islam is very concern about human interaction with the environment and is the main focus in performing ibadah in daily lives.

Several other principles of ibadah and akhlak are also in congruence, for example; the human interaction with flora, fauna, metaphysical entities and amongst human themselves. 
For example, Islam was first introduced with its contents that bring a manifestation of equality and justice. Many evidences accentuate on the importance of interaction amongst humans that should be meandered in harmony and full of respect. Traditionally, social lifestyle of the muslim society is known as:

He is not of us who does not have kindness for our young and respect for our old. (Narrated by Abu Daud \& At Tirmizi)

In short, Islam has underlined many adab and ethics of human relations from various aspects such as; husband and wife, children and parents, teacher and students, with neighbours, with friends, leader and the people, muslims and non-muslims and many more.

Plants or flora is substantial entities that always interact and have a big contribution in human's life. In the Holy Quran, flora is given a special attention and there is even a surah named after a plant, At Tin (the fig tree). Furthermore, there are numerous verses that mention about human interaction with flora; e.g An Nahl: 12, Al An'am: 141, Al Anbiya'; 78 and etc. Islam also stresses on several principles related to human interaction with flora; for instance:

- Protecting and conserving flora and derivates in its natural forms; flowers in their colourful hues and leaves in their green tones.

This world is beautiful and green and Allah has made you His representatives on it and He sees (all things).

(Narrated by Muslim)

- $\quad$ Avoid cutting, shearing or causing the plants to die without a reasonable excuse

- Make use of the plants appropriately

Islam is also very particular about human interaction with animals. Despite the fact that most animals are consumed as food and manipulated for human's advantage, the interaction should remain in a positive situation. The Holy Quran itself includes the names of animals as the title of some verses such as Al An'am (farm animals), Al Baqarah (calf), An Naml (ants), Al 'Ankabut (spider), and Al Fil (elephant). Meanwhile, human interaction with fauna is stated in the Holy Quran as in the verses of Al Mu'minun: 80, Al An'am: 142, Yasin: 71-73 and many more. The history has told the consequence of hell torture just because a person abused a cat, while another person was rewarded with heaven because of his good deeds to a dog. This distinctly establishes the evidence of the significance of human interaction with fauna. Amongst the samples of principles of human interaction with fauna are:

- Slaughtering animals as food. This is to avoid suffering of the animals due to cruel acts before killing them. 
- $\quad$ Neither harmless animals nor harmful ones should be killed or encouraged to be put to death as long as they do not attack or harm us.

- Humans are not allowed to kill animals (including harmful ones) by burning or sinking them in water to avoid unbearable suffering prior to their death.

- $\quad$ No animals are to be used or manipulated for the purpose of entertainment such as cock fighting, bull fighting and such. Rasulullah (PBUH) said:

Anyone who kills a sparrow without a good reason will be called to account by God at the Last Judgement.

(Narrated by An Nasai \& Ibn Hibban)

Human interaction with the environment in Islam is very interesting as it also discusses human interaction with metaphysical environment. This context is never discussed by Western scientists, nor by their activists or environmentalists. Some samples of human interaction with these metaphysical entities, as extracted from various prophetic traditions are:

- $\quad$ One should not be naked while bathing notwithstanding he/she is alone in the bathroom. It is to obey the rules of covering the aurat and at the same time, respecting the angels that are always around us.

- It is encouraged to recite the doa for a group although one is alone, that is to celebrate the muslim jinns that could also be around.

- $\quad$ Give salam while entering a mosque, despite it is empty.

- Respect quiet places and under the trees that could be a recreational area for jinns and the like.

- Bones of slaughtered animals should be properly cleaned and it is encouraged to hang them on the trees as food to the jinns.

- $\quad$ Recite certain doas as a hint of announcing our arrival to certain places such as the jungle, empty houses and so on.

- It is not allowed to kill a white snake as long as it does not harm you, because it could be a jinn that needs a shelter.

\subsection{Islamic Philosophy on Environmental Atitude: An Analysis from Quranic and Prophetic Resources}

The modern environmental theory by western scientists did not come up with a holistic solution. In short, the philosophy of Islamic environmental ethics theory as discussed by scholars like Professor Dr. Seyyed Hossein Nasr, Ziauddin Sardar, A. R Agwan and some others can be generally concluded and simplified into five rationales (rukun) namely tauhid, khilafah, amanah, wasatiah and tawazun. These five rationales can be further explained into simpler guidelines and should be the pre-requisites to construct the codes of Islamic environmental ethics. Amongst the criteria that should be the fundamentals and emphasized in the Islamic environmental ethics are: 


\subsubsection{Tauhidic}

Understanding of the environment, hierarchy, roles and of the attitude of the consumers must be based on the main reference; the wahyu. All decisions with regards to environmental conservation should be maneuvered by the guidelines stipulated by Allah and should not be conducted and meant for the advantages of any entities in the ecosystem. In other words, the extreme personal interests of humans, animals or other ecosystem should not be in the agenda at all. Islamic environmental conservation should frame the importance of wahyu as the primer guidance or in simpler terms, as a Godoriented interaction. All orders from Allah should be on top priotity of all other entities; regardless illogical under certain circumstances. At the same time, it resembles humans as the caliph that lay the precedence of the contents of Al Quran and Al Hadith as the reference without putting aside the welfare of environmental ecosystem. In the meantime, all ijtihadiyyah decisions should stress on the principles of Al Quran and Al Hadith rather than zealotry on logical thinking. The tauhidic concept based on the God as the Creator like this actually ensures total environmental conservation in a more balanced way. Dr Ali Shariati (Agwan, 1997) stated:

In tauhid, it is all about monotheism, hence humans are scared only to one Power and only subject to one Juror, facing only one Qiblah with hope and fear to The Only One. All the others are not right. Tauhid gives humans freedom and honour. Obeying Him uncompromisingly aids human to fight other powers (Ziauddin Sardar, 1985).

\subsubsection{Caliphatic}

Humans are assigned by Allah as the caliph, with the responsibility (amanah) to manage and administer the environment. The environment acts as the realm for humans to conduct the assigned tasks before being evaluated by Allah. However, humans are not left alone to bear the important duties, instead they are guided by syariat via wahyu. A caliph with strong belief on tauhid will not find difficulties in performing the syariah tasks. Humans who hold strongly and realize their obligation towards Allah when accepting the trust and stewardship (amanah khilafah) will never commit harms on any environmental entities under their stewardship (khilafah). This is mentioned in the Holy Quran:

We did indeed offer the Trust to the Heavens and the Earth and the Mountains; but they refused to undertake it, being afraid thereof, but man undertook it, He was indeed unjust and foolish

(Al Ahzab: 72)

Based on the awareness that we are created particularly as caliph to worship Allah, humans should equip themselves with suffcicient knowledge to understand the concept of environment to be administered. With the awareness and realization of the amanah and syariat, harmonious human interaction with the environment is a guarantee. This is in agreement with a muslim scholar, Parvez Manzoor (Agwan, 1997) who claimed: 
By its application, temporal contingencies are judged by eternal imperatives, moral choices are transformed into options for concrete action and ethical sentiment is objectified into law. It is in fact the problem-solving methodology of Islam par excellence. Theoretical Islamic search for an environmental ethics must pass through the objective framework of Shari ah in order to become operative and be part of the Islamic history. Syariah thus provides both the ethical norms and the legal structure within which muslim state(s) may make actual decisions pertaining to concrete ecological issues. Syariah is not only indispensable for decision-making in an Islamic context, but its moral realism also provides excellent paradigms for theoretical discussion of Islamic ecological philosophy.

Therefore, it is concluded that whatever theories and ideologies applied in the context of environmental science, as long as it is based on the concept of stewardship (khilafah) that carries the responsibilities (amanah) assigned by Allah in implementing the syariah application, it is undoubtedly leading to sustainable environmental management and conservation.

\subsubsection{Welfarial}

The environment is created with functions to contribute and serve the human beings. This is understandable by many evidences, as one of them explained:

And they (the animals) carry your heavy loads to lands that you could not (otherwise) reach except with souls distressed: for your Lord is indeed Most Kind, Most Merciful.

(An Nahl: 7)

There are numerous other verses that narrate on the contribution of environmental entities to humans as mentioned in the verses of An Nahl: 5, 8, 11, 16, 67, Yasin: 36, Al An'am: 141, 143, Al Mu'minun: 80 and many more.

In today's modern world, commercial values are unreasonably worshipped to the extent that entities in the environmental ecosysytem are also valued based on their commercial status. In Islam, social and general welfare should be given a priority more than personal interests or minority entities. Furthermore, in fighting for the rights specified for environmental entities, especially humans as the administrator or manager, the values of responsibility should come before the rights. In the cycle of environmental entity, the interrelated interaction will be harmonious and balanced when each entity performs their roles and responsibilities respectively, hence completing each other. Each entity that cares for and gives priority on other entities will create a mutual respect thus leading to a better interaction amongst them. In this case, problems are usually triggered by humans, jinn or devils because other creations have been clearly stipulated by Allah as obedient to His rules (sunnatullah). This concept indirectly solves the extreme theory of anthropocentrism that puts commercial value as the utmost importance in determining the hierarchy of interaction between environmental entities. 


\subsubsection{Moderate}

Islam encourages moderation in all acts and practices. This corresponds to a prophetic tradition which is:

"Be moderate and stand firm in trouble that falls to the lot of a muslim

(as that) is an expiation for him; even stumbling on the path or the pricking of a thorn (are an expiation for him)."

(Narrated by Bukhari dan Muslim)

Even Rasulullah (PBUH) himself stated that the best practice of all is in moderation. The same applies to environmental conservation, as unreasonable excess and taksub will bring more harm rather to the objectives. For instance, deer rearing in Australia once ago that grew drastically and rapidly when the population of the predator entity were attacked and perished significantly. As a result, the food chain is affected when they died due to high competition amongst themselves and starvation. Exuberant steps that are not synchronized with the nature, especially in terms of making use of the God's gifts clearly lead to damage. In view of instruction by Rasulullah (PBUH) on ummatan wasatan, the importance of moderation is justified in which all constituents have their due position in relation to each other.

In short, whatever guidelines used that suit the reality, human interaction with the environment should not be overweening and should avoid excess or taksub. The Islamic theory and philosophy never accentuate on opposites because of the moderation in constructing them by the same main references (Al Quran dan Al Hadith) in harmony of the environmental philosophy. The theory or philosophy in Islam does not incline to opposition due to its moderation in constructing the philosophy and theory that suit the same main reference, contemplating a harmonious environmental philosophy that compiles all views and applications. Theories like anthropocentrisme, ecocentrisme, animal rights, technocentrisme or any other isme created by Western extremists are philosopihies accepted by Islam moderately, without bias on any and not totally against any.

\subsubsection{Balanced}

The environment is readily created balanced and of the best measure specified by Allah. There are numerous verses in the Holy Quran that discuss and explain the balance and measures that Allah has fixed in the creation of the universe. The tawazun concept should steer the actions and decisions in the protection and interaction with the environment. The pairing concept, for instance, should be assimilated so as to hinder the wrongdoings on the environmental entities. The harmonious balance in the ecosystem cycle has been intelligently and perfectly created by Allah. Anything lacking or excessive in the ecosystem cycle may lead to continuous harm and spread to other entities in the cycle. Cutting down green trees that provide oxygen as well as consuming carbon dioxide in a way disturb the natural cycle, hence killing entities such as humans and animals. Besides, water distillation 
process to its original state $(\mathrm{H} 20)$ meant to purify it from various elements actually rips off the nutrient and energy in the water that we drink.

(Allah) Most Gracious! It is He Who has taught the Qur'an. He has created man: He has taught him speech (and intelligence). The sun and the moon follow courses (exactly) computed; And the stars and the trees - both (alike) bow in worship. And the Firmament has He raised high, and He has set up the Balance (of Justice),

(Ar Rahman: 1-7)

Glorify the name of thy Guardian-Lord Most High, Who hath created, and further, given order and proportion; Who hath ordained laws and granted guidance.

(Al A'la: $1-3$ )

The same applies to the balance in other contexts such as in evaluating the hierarchy of environmental entities based on material and non-material values. The values of each entity should be made in a reality context without prejudice on any. Another factor to be considered is the balance of concern on environmental conservation; physically and spiritually and the balance to acquire short term (duniawi) and long term (ukhrawi) returns.

And seek, with the (wealth) which Allah has bestowed on thee, the Home of the Hereafter, nor forget thy portion in this world: but do thou good, as Allah has been good to thee, and seek not (occasions for) mischief in the land: for Allah loves not those who do mischief.

(Al Qasas: 77)

Understanding of the balance in the environment created by Allah should be apprehended and utilized as the core in the application of environmental theory, especially in today's world that sees human greed for their insatiable personal interests that blindfolds them from the real perspective. This consequently leads to opposition, negative competition and fatality in some circumstances. The balanced Islamic concept is in agreement with the moderation concept, hence it should be enhanced based on the fundamentals of tauhid as well as the awareness of trust and stewardship (amanah khilafah).

With the theory application based on the five abovementioned rationales (rukun), environmental philosophies should be inferred more efficiently and effectively in any flexible ways possible. Islam has fixed various guidelines in rules/orders, prohibitions, suggestions and even fundamental principles to be deliberated with research and innovation based on human intellectual for environmental development. As the only perfect (syumul) religion in all aspects, it is undeniable that the evidences in the Holy Quran and Al Hadith are the principal reference that has summarized diverse principles for us to obey. Even the previous muslim scholars have substantially contributed to the growth, research and the arrangement of guidelines regarding human interactions with the environment as well as in the aspect of environmental management. 


\section{0 Conclusion}

Finally, our understanding on Islamic philosophy especially Quranic and Prophetic teaching as primary sources will lead man to a clear paradigm in inculcating good behavior and attitude towards the environment; and of course it would be part of ibadah which is promised with delayed rewards in the Day of Hereafter. Islam views the attitude of interaction in the environmental ecosystem as a big issue when the trust and stewardship (amanah khilafah) are granted to humans as an important appointment to manage and administer the environment. Each and every elements in the environment created by Allah is significant and functional, none is created without purposes. The creations are interrelated and should be managed wisely. In the state where many Western scientists and environmentalists accuse the religions (Christian and Jew) as the environmental crisis factor and the obstacle to a sustainable environment due to the manipulative power of humans (Mohd Noor Ramlan, 1999); Islam emerged as the best alternative solution in which its perspective is extensive and orthodox. Furthermore, the openness of Islam in adapting to the reality is the main pillar towards mounting it as a way of life that is environmental friendly without tarnishing the functions and status of human as a caliph. Reference on the theory of comprehensive environmental ecosystem should be made on the main sources; Al Quran dan Al Hadith as the operation manual of the environment as well as intelligentsias who verify the direct interpretation via research and scientific evidence in ecology and cosmology like Al Biruni, Al Idrisi, Ibn Khayyam, Al Jahiz, Ibn Sina, Al Qazwini, Ad Damiri, Al Baghdadi, As Suyuti, Ibn Batutah and many more.

\section{References}

Agwan, A. R. (1997). Islam and The Environment. Kuala Lumpur: Synergy Book International.

Abdul Halim Sulaiman, Dr. (1998). "Pertimbangan Ekologi Dalam Pengurusan Alam Sekitar": Seminar Alam Sekitar: Pengurusan Bijak Alam Anugerah Tuhan. Kuala Lumpur: IKIM 27-18 Oktober 1998.

Bhatti, Engr. Akhtar K. and Gul-e-Jannat, Dr. (1994). The Holy Quran on Environment. Pakistan: Royal Book Company.

"Environmental Ideologies" [Environmental Philosophy and Ethics: Introduction and Rationale]. April 11, 2002. http://www.ecospace.newport.ac.uk/philosophy/ cssecotech.htm

"Environmental Values" [Anthropocentrism: A Misunderstood Problem]. April 13, 2002.

http://www.erica.demon.co.uk/EV/EV603.html

"Ecocentrism vs Anthropocentrism" [Ecocentrism vs Anthropocentrism: Green Nature]. April 13, 2002. http://www.greennature.com/article.php?sid=469

"Classifying Environmentalisme" [A Critical Introduction to Technocentrism and Ecocentrism]. May 16, 2001. http://www.greenwich.ac.uk.htm 
Jamaluddin, M. J. (1996). Impak Pembangunan Terhadap Alam Sekitar. Bangi: Universiti Kebangsaan Malaysia. Mohd Noor Ramlan (1999). Ekologi Asas dan Alam Semulajadi Terpilih. Shah Alam: Biroteks Universiti Teknologi Mara.

Qushani, Mehdi (1986). The Holy Quran and The Science of Nature. Tehran: Islamic Propogation Organisation.

Samsu Adabi Mamat \& Mohd Bustaman Abdul Aziz (2001). "Al Quran, Manusia dan Falsafah Al Quran": National Seminar Environmental Management 2001: Current Development and Future Planning. Bangi: Universiti Teknologi MARA 14-15 Ogos 2001.

The Dorling Kindersley (1998). History of The World [Revised Edition]. London: Dorling Kindersley Limited.

Uthman El Muhammady (1998). "Perspektif Pengurusan Alam Sekitar: Islam dan Alam Sekitar": Seminar Alam Sekitar: Pengurusan Bijak Alam Anugerah Tuhan. Kuala Lumpur: IKIM 27-18 Oktober 1998.

Wan Mohd Azam Mohd Amin, Dr. (1996). "Prinsip-prinsip Umum Penjagaan Alam Sekitar Menurut Al Quran dan As Sunnah": Dakwah April 1996 Bil 227: 19-25.

Ziauddin Sardar (1991). Sentuhan Midas (Terjemahan). Kuala Lumpur: Dewan Bahasa dan Pustaka.

Ziauddin Sardar (1990). Masa Hadapan Islam: Bentuk Idea Yang Akan Datang (Terjemahan). Kuala Lumpur: Dewan Bahasa dan Pustaka. 